\title{
Publisher Correction: Immunoprophylactic and immunotherapeutic control of hormone receptor-positive breast cancer
}

Aitziber Buqué $\mathbb{D}$, Norma Bloy, Maria Perez-Lanzón, Kristina Iribarren, Juliette Humeau, Jonathan G. Pol, Sarah Levesque, Laura Mondragon, Takahiro Yamazaki (D), Ai Sato (D), Fernando Aranda (1), Sylvère Durand, Alexandre Boissonnas, Jitka Fucikova, Laura Senovilla, David Enot, Michal Hensler, Margerie Kremer, Gautier Stoll (10, Yang Hu (D), Chiara Massa, Silvia C. Formenti (D, Barbara Seliger, Olivier Elemento, Radek Spisek, Fabrice André (1), Laurence Zitvogel, Suzette Delaloge (1), Guido Kroemer (1) \& Lorenzo Galluzzi (D)

Correction to: Nature Communications https://doi.org/10.1038/s41467-020-17644-0, published online 30 July 2020.

The original version of this Article contained an error in Fig. 1. In Fig. 1e, the label "ER-WT $(n=12)$ " was inadvertently duplicated. The red curve should have been labelled "ER-AF20 $(n=12)$ ". This error has now been corrected in both the PDF and HTML versions of the Article.

Published online: 17 September 2020

\footnotetext{
(c) (i) Open Access This article is licensed under a Creative Commons Attribution 4.0 International License, which permits use, sharing, adaptation, distribution and reproduction in any medium or format, as long as you give appropriate credit to the original author(s) and the source, provide a link to the Creative Commons license, and indicate if changes were made. The images or other third party material in this article are included in the article's Creative Commons license, unless indicated otherwise in a credit line to the material. If material is not included in the article's Creative Commons license and your intended use is not permitted by statutory regulation or exceeds the permitted use, you will need to obtain permission directly from the copyright holder. To view a copy of this license, visit http://creativecommons.org/licenses/by/4.0/.
}

(c) The Author(s) 2020 